\title{
ALIH TEKNOLOGI BUDIDAYA LADA ORGANIK SEBAGAI PAGAR HIDUP KEPADA MASYARAKAT DESA KEBONAGUNG, SIDOHARJO, WONOGIRI
}

\author{
Widyatmani Sih Dewi*, Mujiyo, Rahayu \\ Program Studi Ilmu Tanah, Fakultas Pertanian, Universitas Sebelas Maret \\ Jl. Ir. Sutami No. 36A, Surakarta \\ *Korespondensi: wsdewi2000@gmail.com
}

\begin{abstract}
ABSTRAK
Masyarakat desa Kebonagung, Kec.Sidoharjo, Kabupaten Wonogiri mempunyai visi ingin mengembangkan desanya menjadi desa agrowisata organik terpadu. Saat ini, di desa Kebonagung telah dikembangkan padi organik dan buah naga organik. Masyarakat ingin mengembangkan tanaman lada secara organik, baik sebagai tanaman pagar maupun di tanam di lahan pekarangan mereka, karena lada bernilai ekonomi tinggi. Permasalahan yang dihadapi adalah mereka belum mengetahui teknologi budidaya lada secara organik, dan juga belum mengetahui apakah lahannya sesuai untuk untuk budidaya lada atau tidak. Kegiatan pengabdian ini bermitra dengan: (1) Asosiasi Pertanian Organik "Wono Agung” (APOW) dan (2) Kelompok Tani Sedya Maju. Kedua mitra berlokasi di desa Kebonagung.Tujuan dari program ini adalah: (1) alih teknologi dari perguruan tinggi kepada mitra tentang budidaya tanaman lada secara organik sehingga mitra mengembangkan lada secara organik dengan teknologi penanaman secara benar, maupun (2) memberikan informasi ilmiah tentang kesesuaian lahan di Kebonagung untuk budidaya tanaman lada. Metode yang digunakan meliputi: focus group disccusion (FGD), penyuluhan, praktik budidaya lada organik, dan pemantauan. Hasil menunjukkan bahwa mitra begitu antusias dalam menerima teknologi yang dibagikan karena memiliki pengharapan lada mempunyai nilai jual yang tinggi, dan mereka juga segera mempraktikkan budaya lada dari bibit yang dibagikan secara cuma-cuma. Berdasarkan hasil kajian ilmiah, desa Kebonagung sesuai untuk budidaya lada organik dengan pengelolaan tertentu.
\end{abstract}

Kata kunci: alih teknologi, budidaya lada organik, Kebonagung, APOW, Wonogiri

\section{PENDAHULUAN}

Desa Kebonagung, merupakan salah satu desa dari 10 Desa dan 2 Kelurahan yang ada di wilayah Kecamatan Sidoharjo, Kabupaten Wonogiri, terletak sekitar $20 \mathrm{~km}$ ke arah Timur dari Kota Wonogiri. Desa Kebonagung berjarak sekitar $5 \mathrm{~km}$ ke arah Selatan dari Kec. Sidoharjo. Di wilayah Desa Kebonagung terdapat 9 Dusun, meliputi: Dusun Kebonagung, Sanjan, Godokidul, Geneng, Sumberejo, Godolor, Kajang, Gupit Kulon, Gupit Wetan (Humas Wonogiri 2017).

Desa Kebonagung merupakan desa yang merupakan cikal bakal berdirinya Asosiasi Petani Organik Wonogiri "Wono
Agung" (APOW). Mayoritas penduduk mengandalkan pertanian sebagai mata pencahariannya. Kelebihan masyarakat Kebonagung adalah relatif masih banyak pemuda yang menekuni pertanian sebagai profesinya, bahkan mereka mengembangkan pertanian organik, di bawah koordinasi APOW. Jumlah anggota APOW mencapai lebih dari 100 orang yang tergabung dalam beberapa kelompok tani, seperti: Kelompok Tani Sedya Maju, Kelompok Tani Sumber Rejeki 1, Kelompok Tani Sumber Rejeki 2, dan Kelompok Tani Sido Luhur, dan lainlain. Kegiatan Pengabdian kepada masyarakat ini bermitra dengan Asosiasi Pertanian Organik "Wono Agung" yang diketuai oleh Bapak Hardiyan Kusuma Djati 
dan Kelompok Tani Sedya Maju yang diketuai oleh Bapak Sugeng Trisno.

Anggota APOW maupun Kelompok Tani Sedya Maju mayoritas masih mudamuda dan mempunyai keinginan yang kuat dalam membangun desanya. Mereka memiliki visi menjadikan desa Kebonagung, Kec. Sidoarjo, Kabupaten Wonogiri sebagai kawasan wisata pertanian organik. Etos kerja dan kecintaan anggota terhadap pertanian organik ini telah terbukti dengan budidaya padi sawah secara organik dan buah naga secara organik yang telah memperoleh sertifikasi dari Lembaga Sertifikasi Organik Seloleman (LeSOS). Kedua mitra ingin mengembangkan lada organik di desanya sehingga desa Kebonagung menjadi kawasan agrowisata pertanian organik terintegrasi antara padi + buah naga + lada organik.

Lada atau merica (Piper nigrum L) merupakan rempah-rempah yang berbentuk biji yang dipanen dari tanaman dengan nama yang sama yaitu lada. Lada merupakan salah satu komoditas andalan eksport Indonesia (Yuhono, 2007), dan hampir 80\% hasil lada dari Indonesia dieksport ke luar negeri (Wikipedia, 2016). Lada bermanfaat untuk bumbu dapur, minuman yang menghangatkan badan, dan juga berkasiat obat, seperti obat asma, masuk angin, diare, impotensi, reumatik, dan malaria. Lada atau merica yang juga dikenal sebagai King of Spices merupakan tanaman yang berasal dari India. Sebutan merica digunakan di daerah Sumatra Barat dan Sulawesi, di Jawa Tengah dan Timur disebut merico, di Jawa Barat disebut pedes, sedangkan di Bangka-Belitung dan Kalimantan dikenal dengan sebutan sahang. Buah merica Indonesia sudah dikenal dunia sejak sebelum perang dunia kedua. Saat itu daerah penghasil utama merica adalah Lampung yang memproduksi merica hitam yang dikenal dunia dengan sebutan 'Lampung black pepper', dan Bangka-Belitung yang memproduksi merica putih yang dikenal dengan sebutan 'Muntok white pepper'. Saat ini tanaman merica telah tersebar di Jawa, Sumatra, Kalimantan dan Sulawesi (Manohara dan Wahyuno, 2013). Lada mempunyai peranan sangat besar di dalam perekonomian nasional, sebagai tumpuan hidup bagi 327.061 Kepala Keluarga Tani Indonesia (Wahyudi 2010; Panggabean dkk., 2016). Lada berperan sebagai penggerak perekonomian di sentra-sentra produksi dan sumber pendapatan sebanyak 46.620 petani lada (Panggabean dkk., 2016). Lada Indonesia sebagian besar diekspor ke Amerika Serikat, Singapura dan Belanda dalam bentuk lada putih dan lada hitam. Namun, dalam dasawarsa terakhir usaha tani lada mengalami degradasi, baik luas areal maupun produksinya. Salah satu penyebabnya adalah makin sedikitnya petani muda yang bersedia untuk bertani lada (Wahyudi 2010). Tingginya permintaan konsumen terhadap lada maka perlu dilakukan penyediaan produksi untuk pemenuhan kebutuhan tersebut, sehingga peluang untuk membudidayakan lada masih sangat terbuka, baik untuk pasaran lokal maupun internasional.

Pagar merupakan komponen penting yang biasanya dijumpai pada setiap rumah, berfungsi sebagai pembatas antara lingkungan rumah dengan lingkungan luar dan juga bisa digunakan untuk mempercantik rumah. Pagar dalam bayangan masyarakat saat ini adalah pagar yang dibuat dari bahan besi atau kawat. Pagar yang seperti itu memang menjadi tren, khususnya untuk masyarakat di perkotaan. Berbeda dengan keadaan masyarakat di pedesaan, pagar rumah biasanya menggunakan pagar hidup. Pagar hidup adalah sebutan untuk pagar yang dibentuk dari tanaman atau pohon yang fungsinya sebagai pagar. Pagar hidup ini bisa ditanam menggunakan berbagai macam tanaman pagar asalkan memiliki batang yang cukup kokoh dan daun yang juga rimbun (Admin, 2015). Dibandingkan dengan jenis pagar yang lain, pagar hidup mempunyai 
beberapa kelebihan, yaitu : 1) Tidak perlu diganti setiap tahun, 2) Dapat dibentuk sesuai dengan keinginan, 3) Untuk beberapa jenis pagar hidup dapat menghasilkan bahan makanan atau obat-obatan, sehingga bermanfaat bagi kesehatan keluarga (Niaga, 2012).

Di Desa Kebonagung, Kecamatan Sidoarjo, Kabupaten Wonogiri, pagar sebagai pembatas pekarangan rumah hampir seluruhnya merupakan pagar hidup, namun kebanyakan merupakan pagar hidup dari tanaman "teh-tehan". Selain itu, di desa ini banyak lahan pekarangan yang belum termanfaatkan dengan baik, oleh karena itu masyarakat ingin mengembangkan lada secara organik. Lada dipilih sebagai tanaman pagar karena: (1) lada dapat tumbuh dan berproduksi baik pada kondisi agroklimat seperti Wonogiri, (2) prospek pemasarannya terbuka lebar, baik pasar lokal, regional, nasional, bahkan internasional, (3) harga jual tinggi dan (4) budidayanya relatif mudah. Permasalahan yang ada adalah anggota kedua mitra belum memiliki pengetahuan dan keterampilan yang cukup dalam budidaya lada secara organik dan belum mengetahui apakah lahannya sesuai untuk budidaya lada atau tidak.

Tujuan dari kegiatan pengabdian ini adalah: (1) Alih teknologi dari UNS kepada mitra tentang budidaya tanaman lada secara organik di Kebonagung, dan (2) Memberikan informasi ilmiah tentang kesesuaian lahan di Kebonagung untuk budidaya lada.

\section{METODE PENGABDIAN}

Metode yang digunakan dalam kegiatan pengabdian ini meliputi:(1) Focus group disccusion (FGD); (2) Penyuluhan yang di dalamnya disampaikan materi tentang (a) Teknologi budidaya lada organik, (b) Evaluasi kesesuaian lahan, dan (c) penyerahan bantuan bibit dan sarana prasarana; dan (3) Pendampingan praktik budidaya lada organik, serta (4) Monitoring.

\section{HASIL DAN PEMBAHASAN}

\section{Kegiatan FGD}

Kegiatan FGD (Gambar 1) dilakukan oleh Tim Pengabdi sebanyak empat kali, yaitu: (1) pertama dilakukan untuk mennggali informasi tentang permasalahan dan kebutuhan yang dihadapi kelompok untuk dicarikan solusi. Hasil FGD pertama menunjukkan bahwa masyarakat ingin mengembangkan lada organik sebagai tanaman pagar dan pekarangan untuk menambah ragam produk pertanian organik di Kebonagung, namun mereka belum tahu teknologi budidaya secara organik dan kesesuaian lahan desa Kebonagung untuk budidaya lada. (2) FGD kedua mendiskusikan tentang rencana pengajuan proposal kegiatan Iptek bagi Masyarakat (IbM) dan tahap-tahap pelaksanaan program. (3) FGD ketiga mendiskusikan tentang realisasi pelaksanaan kegiatan, dan (4) FGD keempat mendiskusikan tentang evaluasi kegiatan.

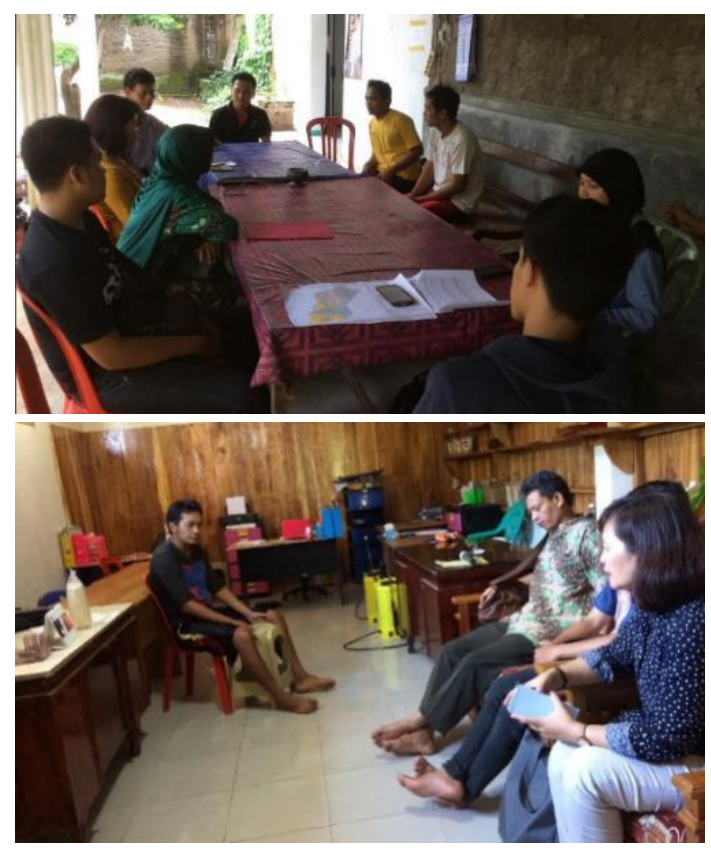

Gambar 1. Beberapa kegiatan FGD untuk menjaring informasi permasalahan yang dihadapi mitra. 


\section{Penyuluhan}

Pada kegiatan penyuluhan ini disampaikan materi tentang (a) Teknologi budidaya lada organik, (b) Evaluasi kesesuaian lahan desa Kebonagung untuk budidaya lada, dan (c) penyerahan bantuan bibit dan sarana prasarana.

\section{Teknologi budidaya lada organik}

Tanaman lada merupakan tanaman yang memerlukan tajar, baik tajar hidup ataupun tak hidup.Tanaman ini pada umumnya tidak suka terkena sinar matahari langsung sehingga perlu penaung, kecuali tanaman lada yang toleran panas, sehingga tanaman ini dapat dikembangkan dengan sistem agroforestri.Syarat tumbuh tanaman lada, antara lain: (1) ketinggian tempat antara $0-$ $1000 \mathrm{~m}$ dpl, namun tumbuh baik pada 300$1000 \mathrm{~m} \mathrm{dpl}$; (2) suhu rata-rata antara $21-27$ ${ }^{\circ} \mathrm{C}$, bahkan sampai $34{ }^{\circ} \mathrm{C}$; (3) kelembaban udara antara 50-75\%, (4) intensitas sinar matahari antara antara 50-70\%, dan (5) curah hujan antara 2000-3000 mm/th dengan bulan basah antara 7-8 bulan. Budidaya lada relatif mudah.

Bibit yang baik untu tanaman lada adalah terjamin kemurnian jenis bibitnya, berasal dari pohon induk yang sehat, bebas dari hama dan penyakit, dan berasal dari kebun induk produksi yang sudah berumur 10 bulan-3 tahun.

Teknik budidaya lada secara organik adalah sebagai berikut:

- Membuat lubang tanam berbentuk limas ukuran atas $40 \mathrm{~cm} \times 35 \mathrm{~cm}$, bawah $40 \mathrm{~cm}$ x $15 \mathrm{~cm}$ dan kedalaman $50 \mathrm{~cm}$.

- Menaburkan kapur pertanian, pupuk kandang 0,75-100 gram/tanaman, dan pupuk organik cair sesuai dengan aturan pakai.

- Mencampur bahan-bahan tersebut secara merata.di dalam lubang tanam.

- Membiarkan lubang tanam 10-15 hari, barulah kemudian menanam bibit.
- Cara menanaman: membuka polibek bibit, lalu menanam bibit dengan menghadapkan bagian yang ditumbuhi akar lekat ke bawah, sedangkan bagian belakang (yang tidak ditumbuhi akar lekat) menghadap ke atas, dilanjutkan dengan pembumbunan.

- Memadatkan tanah dan membuat naungan untk melindungi bibit (jika diperlukan).

Kesesuaian lahan desa Kebonagung untuk budidaya lada

Budidaya lada di desa Kebonagung akan berhasil baik jika lahan di desa Kebonagung sesuai untuk budidaya lada. Oleh karena itu diperlukan penilaian kesesuaian lahan berdasarkan sejumlah parameter atau karaketristik lahan tertentu (Tabel 1).Kesesuaian lahan adalah kecocokan sebidang lahan untuk sistem penggunaan tertentu sedangkan evaluasi lahan merupakan proses untuk menaksir tingkat kesesuaian lahan tersebut (Sukaryorini dan Arifin, 2006). Hasil penilaian evaluasi lahan dapat digunakan sebagai pertimbangan untuk membuat suatu model pengelolaan lahanyang sesuai, didasarkan pada kondisi pembatas yang paling minimum,sehingga meminimalkan potensi kerusakan sumberdaya lahan.

Hasil evaluasi kesesuaian lahan (Tabel 1) menunjukkan bahwa secara umum desa Kebonagung sesuai untuk lada namun dengan beberapa kendala yang dapat diatasi melalui pengelolaan secara organik dan sistem agroforestri.

Beberapa kendala yang ada antara lain: (1) bulan kering yang terjadi di Kebonagung berkisar antara 3-4 bulan sehingga dapat menjadi pembatas untuk tanaman lada. Kendala tersebut dapat dapat diatasi dengan penyiraman dan penambahan bahan organik yang akan dapat meningkatkan kapasitas tanah menahan lengas; (2) kemampuan tanah dalam retensi hara berada pada tingkat sesuai dan perlu mengelolaan supaya menjadi 
sesuai, dan solusinya adalah penambahan pupuk organik atau pembenah tanah organik yang akan meningkatkan kemampuan tanah dalam retensi hara; (3) tingkat ketersediaan hara dari rendah sampai sangat rendah dapat diatasi dengan pemberian pupuk organik; dan (4) tingkat kepekaan terhadap erosi antara ringan atau sedang sampai berat. Hal tersebut dapat diatasi dengan penanaman lada secara agroforestri yaitu menggunakan tanaman penaung dari berbagai jenis pohon dengan berbagai strata tajuk dan kedalaman perakaran yang berbeda-beda. Sistem agroforestri juga akan mengefisienkan penggunaan sumber daya air, cahaya matahari, dan hara.

Tabel 1. Hasil evaluasi kesesuaian lahan desa Kebonagung untuk lada

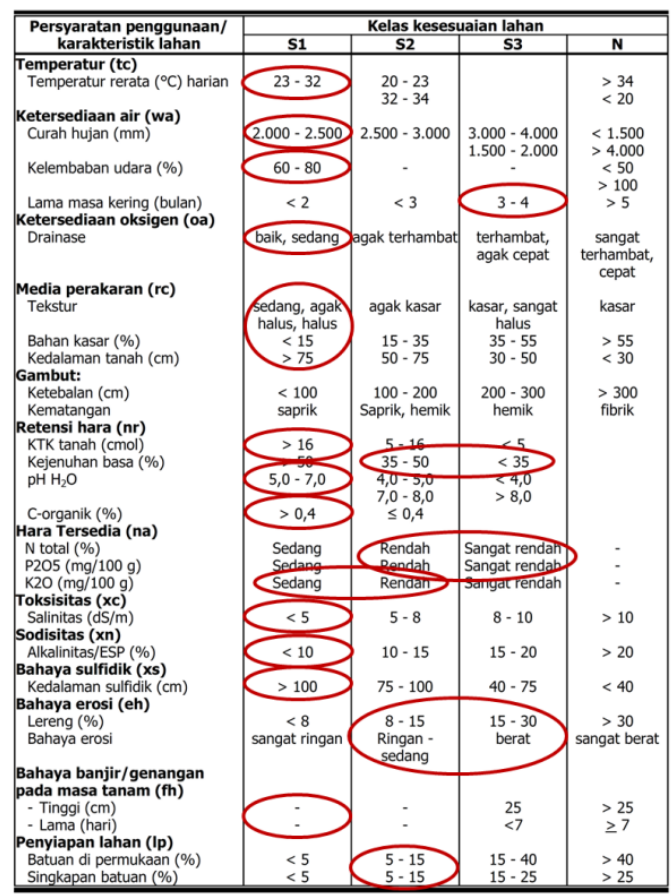

Keterangan: $\mathrm{S} 1$ = sangat sesuai, $\mathrm{S} 2=$ sesuai, $\mathrm{S} 3=$ kelas kesesuaian marginal, $\mathrm{N}=$ tidak sesuai, dan lingkaran merah adalah nilai parameter di desa Kebonagung.

Respon masyarakat terhadap teknologi budidaya organik sangat tinggi karena merka mempunyai pengharapan yang tinggi terhadap prospek panen lada ke depan yang memiliki nilai jual yang tinggi (Gambar 2). Selain itu, informasi tentang hasil evaluasi kesesuain lahan menunjukkan bahwa desa Kebonagung secara umum sesuai untuk lada dengan beberapa pengelolaan yang dapat dilakukan secara organik membuat mereka semakin bersemangat.

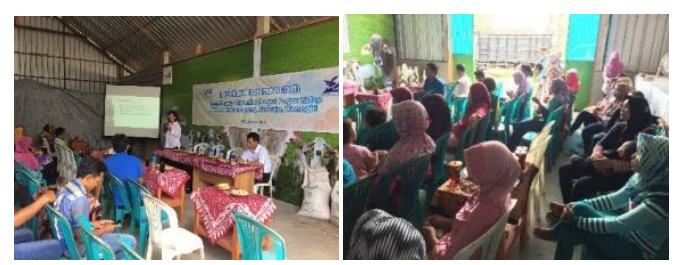

Gambar 2. Antusiasme warga dalam mengikuti penyuluhan budidaya lada secara organik dan prospek pengembangannya di Kebonagung

Penyerahan bantuan bibit dan sarana prasarana budidaya lada kepada Mitra

Pada kegiatan pengabdian ini Tim Pengabdi memberikan bantuan kepada mitra, berupa 600 bibit lada dan 50 tajar beton, serta pupuk organik (Gambar 3).

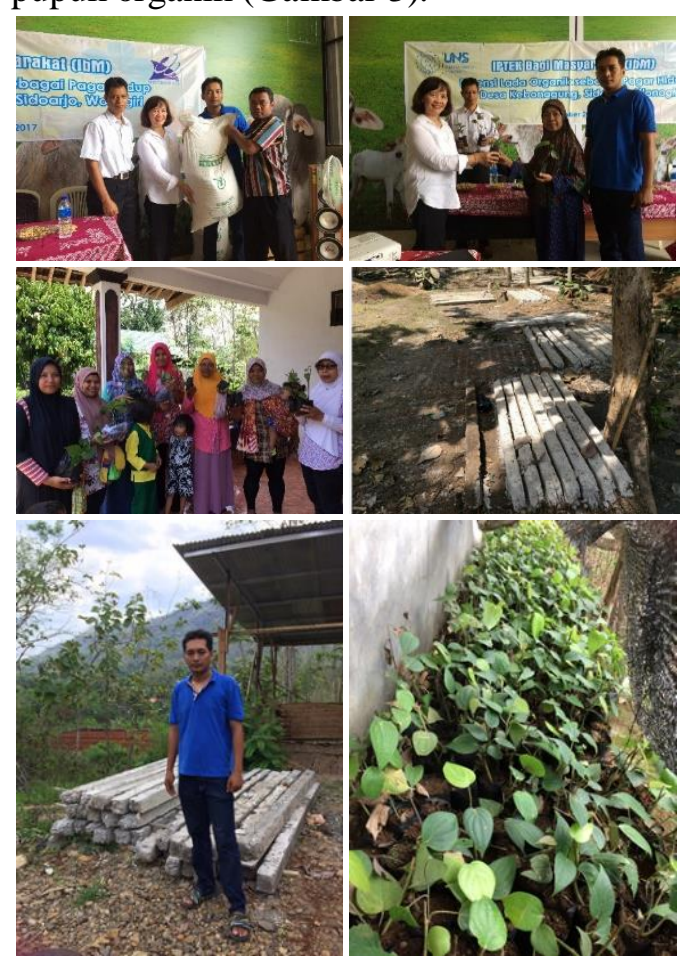

Gambar 3. Penyerahan bantuan bibit lada, tajar beton dan pupuk organik kepada mitra 


\section{Pendampingan praktik budidaya lada organik}

Petani muda dari Kelompok Tani mitra menanam lada secara organik menggunakan bibit yang dibagikan secara cuma-cuma kepada mereka, di lahan pekarangan warga (Gambar 4).

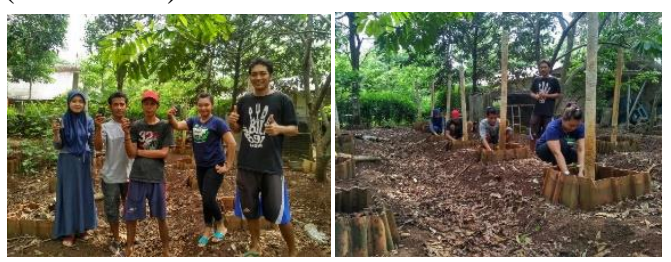

Gambar 4. Penanaman lada secara organik oleh petani muda dari kelompok tani mitra

\section{Monitoring pertumbuhan lada yang ditanam mitra}

Monitoring dilakukan untuk memantau pertumbuhan tanaman lada yang sudah ditanam oleh kelompok tani mitra. Bibit lada yang ditanam menggunakan tajar beton maupun tajar pohon hidup menunjukkan pertumbuhan yang baik (Gambar 5).

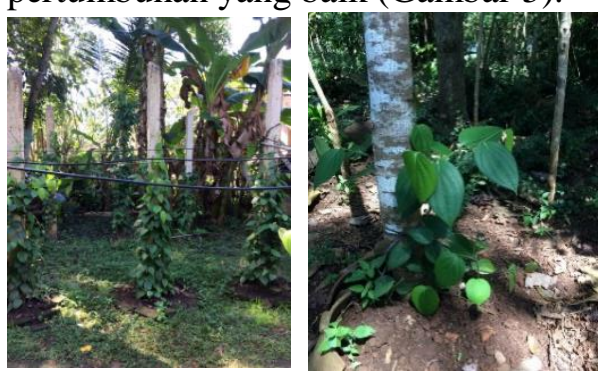

Gambar 5. Pertumbuhan tanama lada yang menggunakan tajar beton maupun tajar pohon hidup

\section{KESIMPULAN DAN SARAN}

\section{Kesimpulan}

1. Lahan di Kebonagung, Kec. Sidoharjo, Kab. Wonogiri sesuai untuk budidaya lada dengan pengelolaan secara organik.

2. Respon warga terhadap alih teknologi budidaya lada secara organik sangat tinggi yang ditunjukkan dengan segera menanam bibit lada yang diberikan secara cuma-cuma.

\section{Saran}

Pertumbuhan lada yang telah ditanam oleh Kelompok Tani perlu dimonitoring pertumbuhannya. Oleh karena itu peran pendampingan dari Perguruan Tinggi (Tim Pengabdi) perlu dilanjutkan untuk tahuntahun ke depan.

\section{UCAPAN TERIMA KASIH}

Tim Pengabdi menyampaikan ucapan terima kasih kepada Direktorat Riset dan Pengabdian Masyarakat, Direktorat Jenderal Penguatan Riset dan Pengembangan, Kementerian Riset, Teknologi, dan Pendidikan Tinggi yang telah mendanai program pengabdian ini melalui skim Program Kemitraan Masyarakat (PKM), Tahun Anggaran 2017.

\section{DAFTAR PUSTAKA}

Admin. 2015. Pagar Hidup, Pagar yang Bermanfaat.

http://www.kompasiana.com/akbarisati on/pagar-hidup-pagar-yangbermanfaat_550e79a7a33311bb2dba81 79. Diakses tanggal 5 Pebruari 2016.

Humas Wonogiri. 2017. Kecamatan Sidoharjo.

http://humas.wonogirikab.go.id/v2/keca matan-sidoharjo/. Diakses 15 November 2017.

Manohara D dan Wahyuno D. 2013. Pedoman Budidaya Merica (Pepper cultivation guide). Bogor, Indonesia: World Agroforestry Centre (ICRAF) Southeast Asia Regional Program.

Niaga M. 2012. Pagar Hidup. http://Niaga.blogspot.co.id/2012/06/pa gar. hidup.html. Diakses tanggal 5 Pebruari 2016.

Panggabean MT, Amanah S, Tjitropranoto P. 2016. Persepsi Petani Lada terhadap Diseminasi Teknologi Usahatani Lada di Bangka Belitung. Jurnal Penyuluhan, 12 (1): 61-73. 
Sugito. 2016. Teknologi Budidaya Lada yang

Baik. http://cybex.pertanian.go.id/teknologi/d etail/2096/teknologi-budidaya-ladayang-baik. Diakses: Senin, 30 Mei 2016, jam 17.14.

Sukaryorini P damn Arifin M. 2006. Pemetaan Kesesuaian Lahan untuk Komoditi Tanaman Buah-Buahan DiKecamatan Munjungan, Kabupaten Trenggalek. Jurnal Pertanian MAPETA 8 (3): 151- 154.
Wahyudi A. 2010. Teknologi Pertanian Sehat Kunci Sukses Revitalisasi Lada. SINAR TANI Edisi 17 - 23 November 2010.

Wikipedia. 2016.2 Lada. https://id.wikipedia.org/wiki/Lada. Diakses: Senin, 30 Mei 2016, jam 17.41.

Yuhono JT. 2007. Sistem Agribisnis Lada dan Strategi Pengembangannya. Jurnal Litbang Pertanian 26(2): 76-81. 